\title{
Antioxidant properties in the oyster mushrooms (Pleurotus spp.) and split gill mushroom (Schizophyllum commune) ethanolic extracts
}

\author{
Arbaayah HH And Umi Kalsom Y \\ ${ }^{I}$ Department of Biology, Faculty of Science, Universiti Putra Malaysia, 43400 Serdang, Selangor, Malaysia. \\ arbaayah_86@yahoo.com \\ ${ }^{2}$ Department of Biology, Faculty of Science, Universiti Putra Malaysia, 43400 Serdang, Selangor, Malaysia
}

Arbaayah HH And Umi Kalsom Y 2013 - Antioxidant properties in the oyster mushrooms (Pleurotus spp.) and split gill mushroom (Schizophyllum commune) ethanolic extracts. Mycosphere 4(4), 661-673, Doi 10.5943/mycosphere/4/4/2

\begin{abstract}
Ethanolic extracts of oyster mushrooms (Pleurotus pulmonarius, P. ostreatus, P. djamor var. djamor and P. djamor var. roseus) and the split gill mushroom (Schizophyllum commune) were successfully investigated for their antioxidant properties. The study was carried out to determine the capability of the extracts to scavenge 2,2-diphenyl-1-picrylhydrazyl (DPPH) radicals, to determine its reducing ability towards ferricyanide complex (FRAP assay) and to determine the concentration of total phenolic content (TPC) and total flavonoids content (TFC) in the macrofungi ethanolic extracts. Inhibition concentration at $50 \%\left(\mathrm{IC}_{50}\right)$ for each extract to scavenge DPPH radicals was detected from $2.75 \mathrm{mg} / \mathrm{ml}$ to $12 \mathrm{mg} / \mathrm{ml}$ where $S$. commune from the fourth flush showed the lowest $\mathrm{IC}_{50}$ value among all tested mushrooms. The greatest ability to reduce ferricyanide complex to ferrous form was observed in $P$. djamor var. djamor at concentration 10 $\mathrm{mg} / \mathrm{ml}$ in both first $(1.23 \pm 0.02)$ and second flushes $(1.23 \pm 0.00)$. Meanwhile, the highest TPC was determined in $P$. djamor var. djamor extract $(51.94 \pm 0.04 \mathrm{mg}$ TAE/g dry weight of extract) whereas $S$. commune gave highest reading of total flavonoid content in TFC assay $(29.80 \pm 0.27 \mathrm{mg}$ $\mathrm{QE} / \mathrm{g}$ dry weight of extract). All the mushroom samples showed appreciable antioxidant properties which therefore, can be promoted as natural antioxidant preference in food and pharmaceutical industries.
\end{abstract}

Key words - 2,2-diphenyl-1-picrylhydrazyl (DPPH) assay - ferric reducing antioxidant power (FRAP) assay - edible macrofungi - total flavonoids content (TFC) - total phenolics content (TPC)

\section{Introduction}

Malaysia, which is located in a tropical region characterized by a warm and humid environment is a great habitat for the growth of edible macrofungi such as oyster mushroom (Pleurotus sp.), split gill mushroom (Schizophyllum commune), mound mushroom (Termitomycetes sp.), shiitake (Lentinula edodes), paddy straw mushroom (Volvariella volvacea), bracket fungi (Ganoderma spp.) and Jew's ear mushroom or locally called as monkey's ear mushroom (Auricularia sp.). Among the macrofungi that have been cultivated for food, oyster mushroom ranked second, behind the button mushroom, Agaricus bisporus (Aksu et al., 1996) with a shared volume of $24.2 \%$ of world production. The use of mushrooms in Malaysia includes in food, processed food, medicines and in remedy preparation. The commercialization of oyster mushrooms 
in Malaysia has increased through time although some local people still depend on the collection of wild edible mushrooms in rural areas.

Macrofungi from the genus Pleurotus, widely known as oyster mushrooms are preferred by many people for their delicate taste, mild yet chewy texture and unique aroma. According to Department of Agriculture Malaysia, the import of mushroom for the local market was about 21077 metric tons in 2007 (Ishak, 2011). Malaysians consume an estimated 324 gram of mushrooms per person per year and this figure is predicted to increase in the future. The world trade of these mushrooms shows an increasing pattern and gives promising opportunity for the traders (Chang, 2001). This trend happens not only because of high demand from consumers but also the ability to apply cheap cultivation strategy. They have been cultivated in large amounts since a long time ago by using lignocelluloses materials such as sawdust, paddy straw, wheat straw and cotton and proven to be successfully cultivated on banana pseudostem, Bahia grass (Martos et al., 2011), bamboo leaves, lawn grasses (Kumari and Achal, 2008), yam peelings (Dioscoria sp.), cassava peelings (Manihot sp.), wild grass straw (Pennisetum sp.) corn straw and oil palm fruit fibers (Okhuoya \& Okogbo, 1991).

The split gill mushroom or locally called as 'kulat sisir' (literally mean as 'comb fungus') is the most common edible mushroom that can be found in many countries including western and eastern regions. For that reason, it is not surprising that this mushroom has always been used as a model type for macrofungi analysis in academic studies and scientific researches. Despite its availability, split gill mushroom is scarce in commercial Malaysian market, probably due to limited sources of natural substrates and its seasonal environment is unsuitable for the development of fruit bodies. Sometimes, this mushroom can be found at weekend market or night market, but usually the price is quite high. Unlike oyster mushroom, split gill mushroom is not commercially cultivated although the substrates are nevertheless the same. The cultivators find it unattractive to grow this type of mushroom due to its low product yield, small fruit body and its ability to degrade substrate in a short period of time compared to other edible mushrooms, which lead to its low biological efficiency.

Edible macrofungi received worldwide attention for their nutritional values such as protein, carbohydrate and antioxidant components such as ascorbic acid, $\beta$-carotene and $\alpha$-tocopherol (Chang et al., 2007; Duru \& Mercan, 2007; Jagadish, Venkata, Shenbhagaraman, \& Kaviyarasan, 2009; Jayakumar, Thomas, \& Geraldine, 2009; Tsai et al., 2009; Wong \& Chye, 2009). Several researches had proven that high amounts of antioxidants may prevent the oxidative stress caused by the presence of free radicals which lead to disorder in physiological effectiveness such as cell damage, generating of cancer cell and brain cell aging (Bejma \& Ji, 1999; Poon, Calabrese, Scapagnini, \& Butterfield, 2004; Wei, \& Lee, 2013). Oxidative stress might occur with the presence of oxidation agents, decrease of antioxidants or both factors. This action will lead to the production of reactive oxygen species (ROS) and free radicals as the harmful by products in oxidation process. Stress may be derived from many sources that affect the human physiological system including from food intake, radiation exposure and radical substances inhalation, and it is closely related to human lifestyle and surroundings.

Antioxidants play an important role in maintaining human health due to their ability to scavenge free radicals in the bodies. Fortunately, human body is designed to have its own defence system such as superoxide dismutase enzyme, glutathione enzyme and catalase to fight harmful substances and prevent cell damages (Halliwell, 1996). However, the consumption of supplemented antioxidants present in our diets such as in fruits, vegetables and mushrooms is very important to offer adequate security. Hence, the objectives of this study are to determine the antioxidant activities, total phenolic content and total flavonoids content in the ethanolic extract of selected commercial mushrooms (Pleurotus pulmonarius, P. ostreatus and P. djamor var. roseus) and cultivated wild edible mushrooms ( $P$. djamor var. djamor and Schizophyllum commune) that are available in Malaysia. 

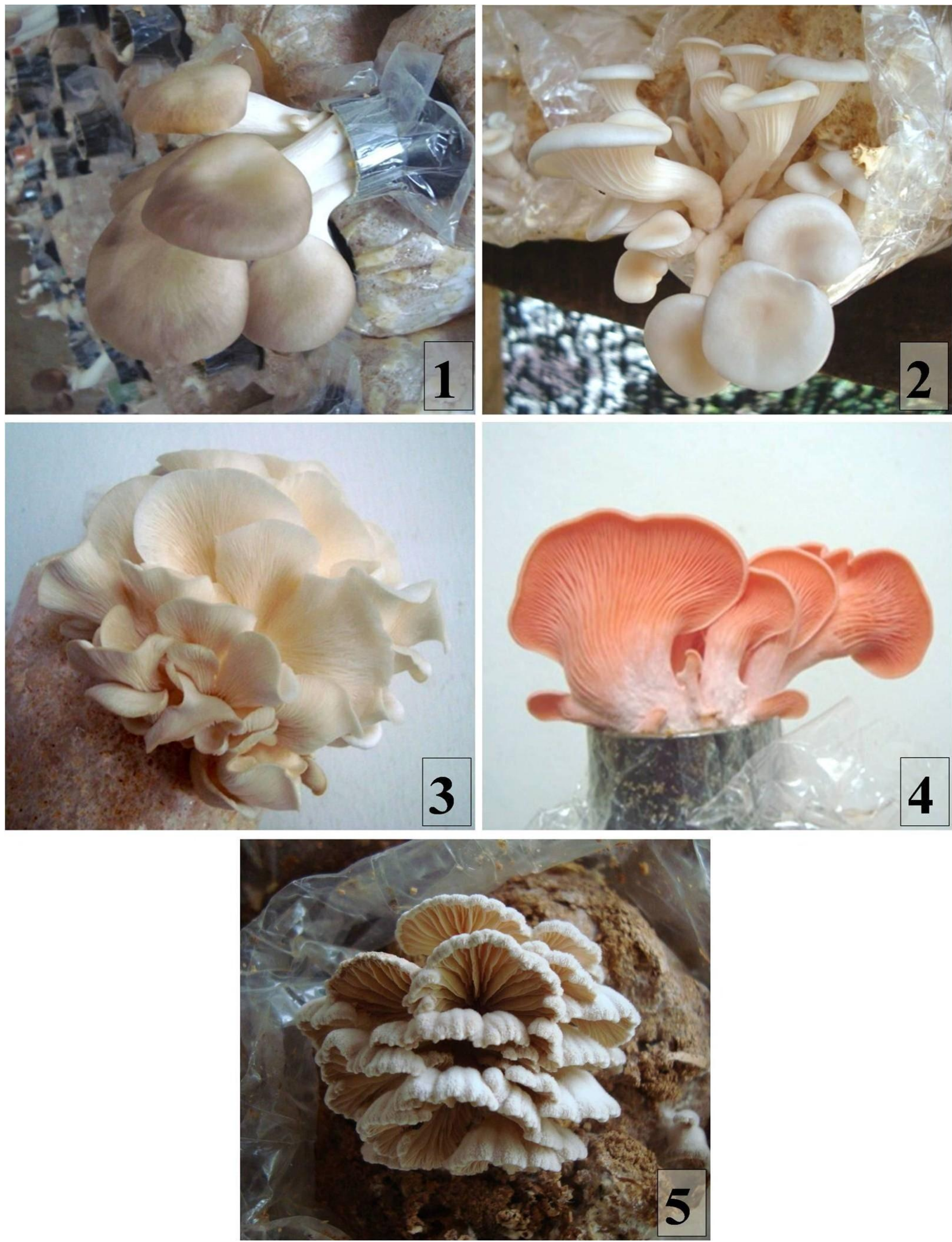

Figs 1-5 - Matured fruit body of oyster mushrooms, Pleurotus spp. and split gill mushroom, Schizophyllum commune. 1 Pleurotus pulmonarius. 2 Pleurotus ostreatus. 3 Pleurotus djamor var. djamor. 4 Pleurotus djamor var. roseus. 5 Schizophyllum commune. 


\section{Materials \& Methods}

\section{Mushroom strains}

Pleurotus djamor var. djamor and Schizophyllum commne were collected from oil palm plantation of Universiti Putra Malaysia (UPM), P. pulmonarius and P. ostreatus were obtained from University Agriculture Park, UPM and P. djamor var. roseus was bought from night markets at Brinchang, Cameron Highland, Pahang, Malaysia. Mushrooms identification was carried out and all specimens were deposited at Mycology Laboratory, Faculty of Science, Universiti Putra Malaysia, Serdang, Selangor, Malaysia.

\section{Fungal isolation and spawn preparation}

The fresh samples $(2 \times 2 \mathrm{~mm})$ were isolated on $9 \mathrm{~mm}$ Petri plate containing Difco ${ }^{\mathrm{TM}}$ Potato Dextrose Agar (PDA) media and observed until the mycelial colony covered the whole plate. Pure cultures of isolates were obtained from subculture preparation and spawn was prepared by using sterile wheat grains. The grains were washed, autoclaved at $121^{\circ} \mathrm{C}$ for 20 minutes and allowed to cool in $100 \mathrm{ml}$ conical flask. The fungal mycelia were inoculated on the grains and the mouth of the flask was covered with aluminium foil and wrapped with parafilm to prevent contamination by insects, fungi and bacteria. The spawn was ready to use for polybag cultivation after the mycelia covered all the grains in the conical flask.

\section{Substrate preparation}

The substrates consist of sawdust, rice meal and calcium carbonate, $\mathrm{CaCO}_{3}$ in 100:10:0.1-1 ratio. Polypropylene bags were filled with $800 \mathrm{~g}$ of substrates with $70 \%$ of water (Norouzi et al., 2008) and the bags were tightly closed with neck and cap then sterilized once in hot steam container for 24 hours. The substrate was allowed to cool down before being injected with mushroom spawn. The regular amount of spawn was $3 \%$ based on the substrate weight (Kalberer and Kunsch, 1974). The bags were subsequently kept in spawn running room with $75-85 \%$ relative humidity until the formation of primordia. Then the bags were uncapped and transferred to the fruiting room to allow the normal development of fruit bodies. The bags were kept in bed position on rack $(240 \mathrm{~cm} \times 90 \mathrm{~cm})$ at $25^{\circ} \mathrm{C}$ with a 12 hours photoperiod and $80-90 \%$ relative humidity. Adequate ventilation was provided to prevent increase of carbon dioxide gas, $\mathrm{CO}_{2}$ concentration in the room which will inhibit the fruit body development (Norouzi et al., 2008).

\section{Preparation of the sample}

Preparation of the mushroom samples was determined according to Tsai et al. (2009). The mushrooms were lyophilized (Labconco, Missouri) and ground to obtain fine powder. About $10 \mathrm{~g}$ samples were extracted by stirring with $100 \mathrm{ml}$ of ethanol at $25^{\circ} \mathrm{C}$ at $20 \times \mathrm{g}$ for 24 hours and filtration through Whatman No. 1 filter paper. The residue was extracted with two additional 100 $\mathrm{ml}$ portions of ethanol as described above and combined ethanolic extracts were concentrated under reduced pressure below $40^{\circ} \mathrm{C}$ to obtain the crude extract. The crude extracts were redissolved in ethanol at concentration $20 \mathrm{mg} / \mathrm{ml}$ and stored at $4^{\circ} \mathrm{C}$ for further analyses.

\section{Scavenging 2,2-diphenyl-1-picrylhydrazyl (DPPH) radicals}

This assay was performed by following the standard method of Bloise (1958) with several modifications. DPPH solution was prepared by dissolving $5 \mathrm{mg}$ DPPH powder in $2 \mathrm{ml}$ of ethanol, sealed in aluminium foil and kept in a fridge. Accurately $100 \mu \mathrm{l}$ of test samples $(0.6-20.0 \mathrm{mg} / \mathrm{ml}) \mathrm{in}$ ethanol was added with $5 \mu \mathrm{l}$ DPPH solution in 96-well microtitter plates. Mixture was incubated in the dark for $30 \mathrm{~min}$. Absorbance was measured at $517 \mathrm{~nm}$ (SpectraMax Plus384, United States) and $\mathrm{IC}_{50}$ value (concentrations of each sample required to give $50 \%$ of the optical density shown by control) was calculated. Inhibition of DPPH free radicals was calculated by using following formula: 
Inhibition of DPPH radical $(\%)=100 \times\left(\mathbf{A}_{\text {control }}-\mathbf{A}_{\text {sample }}\right) / \mathbf{A}_{\text {control }}$

Where, $\mathbf{A}_{\text {control }}=\begin{gathered}\text { Absorbance of the control solution } \text { (containing all reagents except the test } \\ \text { extract) }\end{gathered}$
\[ \mathbf{A}_{\text {sample }}=\text { Absorbance of the test extract } \]

All test analyses were run in at least four replicates and averaged. Standard antioxidants such as quercetin and butylated hydroxyanisole (BHA) were used as positive control.

\section{Determination of reducing power by reducing ferricyanide complex}

The reducing power assay of macrofungi was carried out by using the method described by Oyaizu (1986) with several modifications. Different concentrations of the extract ( 2 to $10 \mathrm{mg} / \mathrm{ml}$ ) in $1.0 \mathrm{ml}$ of distilled water was mixed with phosphate buffer $(2.5 \mathrm{ml}, 0.2 \mathrm{M}, \mathrm{pH} 6.6)$ and $1 \%$ potassium ferricyanide $(2.5 \mathrm{ml})$. The mixture was incubated at $50^{\circ} \mathrm{C}$ for 20 minutes. Aliquots of trichloroacetic acid $(2.5 \mathrm{ml}, 10 \%)$ was added to the mixture and then centrifuged at $1036 \times g$ for 10 minutes. The upper layer of the solution $(2.5 \mathrm{ml})$ was mixed with distilled water $(2.5 \mathrm{ml})$ and $\mathrm{FeCl}_{3}$ solution $(0.3 \mathrm{ml}, 0.1 \%)$. The absorbance was measured at $700 \mathrm{~nm}$ (SpectraMax Plus384, United States). The increasing absorbance of the reaction mixture was taken to mean an increase of reducing power. The standard (BHA) and quercetin were measured by using same procedures.

\section{Determination of total phenolic content}

Total phenolic content in extracts was determined by using Folin-Ciocalteau reagent based on method of Harborne (1989) with several modifications. Each sample $(150 \mu 1,10 \mathrm{mg} / \mathrm{ml})$ was added with distilled water $(1200 \mu \mathrm{l})$ and aqueous sodium carbonate, $\mathrm{Na}_{2} \mathrm{CO}_{3}$ solution $(450 \mu \mathrm{l})$. About $100 \mu \mathrm{l}$ of Folin-Ciocalteu reagent was added to the mixture and agitated. The mixture was allowed to stand for 90 minutes and the absorbance was measured at $760 \mathrm{~nm}$ by using UV/visible spectrophotometer (SpectraMax Plus384, United States). The concentration of total phenolic compunds was calculated based on standard curve of tannic acid $(0.2-1.0 \mathrm{mg} / \mathrm{ml})$ and the results were expressed as mg tannic acid equivalent (TAE) per gram of the extracts which resembled a linear equation, $\mathrm{y}=0.624 \mathrm{x}-0.939$, where $\mathrm{R}^{2}=0.995$.

\section{Determination of total flavonoid content}

This assay was performed by using aluminium choride colorimetric method described by Barros et al. (2008) with modifications. Mushroom extract $(100 \mu l, 10 \mathrm{mg} / \mathrm{ml})$ was mixed with distilled water $(500 \mu \mathrm{l})$ and sodium nitrite, $\mathrm{NaNO}_{2}(5 \%, 30 \mu \mathrm{l})$. The mixture was allowed to stand for 5 minutes. Aluminium chloride solution, $\mathrm{AlCl}_{3} \cdot \mathrm{H}_{2} \mathrm{O}(10 \%, 60 \mu \mathrm{l})$ was added to the mixture and left for 6 minutes. Sodium hydroxide, $\mathrm{NaOH}(1 \mathrm{M}, 200 \mu \mathrm{l})$ and distilled water $(110 \mu \mathrm{l})$ were added to the solution and mixed well. Intensity of the mixed solution was measured at $510 \mathrm{~nm}$ (SpectraMax Plus384, United States) and the concentration of total flavonoids contents were calculated as equivalent to standard quercetin graph $(\mathrm{QE}), \mathrm{y}=0.016 \mathrm{x}-0.031$, where $\mathrm{R}^{2}=0.991$.

\section{Statistical analysis of experimental data}

The data obtained was analyzed by using Microsoft Office Excel 2007 and Statistical Package for Social Sciences 21 (SPSS 21) version software. Mean and standard errors of replications were calculated. One-way analysis of variance (ANOVA) test was performed at 5\% probability to check the level of significance between the variables.

\section{Results}

Oyster mushrooms and split gill mushrooms are edible macrofungi that are indigenous to pan-tropic regions including Malaysia. They are collected wild and commercially cultivated and prepared in cooked dishes and preferred for their taste, texture and aroma. The ethanolic extracts of Pleurotus pulmonarius (phoenix oyster mushroom or grey oyster mushroom), Pleurotus ostreatus (pearl oyster mushroom or white oyster mushroom), Pleurotus djamor var. djamor (pink oyster 
mushroom), Pleurotus djamor var. roseus (pink oyster mushroom) and Schizophyllum commune (split gill mushroom) as shown in figures $1-5$ were screened for their antioxidant activity by four assays named as 2,2-diphenyl-1-picrylhydrazyl (DPPH) assay, ferric reducing antioxidant power (FRAP) or reducing power assay, total phenolic content (TPC) assay and total flavonoid content (TFC) assay. The fungal specimens were currently deposited at the Mycology Laboratory, Department of Biology, Faculty of Science, Universiti Putra Malaysia, Serdang, Selangor, Malaysia.

Generally, tested macrofungi specimens contained $69.26 \%$ to $85.49 \%$ moisture content in fresh fruit bodies (Table 1) where split gill mushroom, Schizophyllum commune was determined to have the lowest moisture content while specimen of oyster mushrooms, Pleurotus spp. showed significantly higher level $(p<0.05)$. Total yield of mushroom ethanolic extracts ranged from 5.13\% to $12.01 \%$ of the fresh weight for all mushroom extract (Table 1). The average yield of extracts were calculated as $9.24 \%, 7.41 \%, 7.252 \%$ and $8.70 \%$ for first, second, third and fourth flushes respectively but the result did not show any discrete trendline with the number of flushes and there was no statistical difference obtained ( $p>0.05$ ). Therefore, we concluded that the number of flushes had no effect on the yield of mushroom extract.

Generally, tested macrofungi specimens contained $69.26 \%$ to $85.49 \%$ moisture content in fresh fruit bodies (Table 1) where split gill mushroom, Schizophyllum commune determined to has the lowest moisture content while specimen of oyster mushrooms, Pleurotus spp. showed significantly higher level $(p<0.05)$. Total yield of mushroom ethanolic extracts was ranging from $5.13 \%$ to $12.01 \%$ of the fresh weight for all mushroom extract respectively (Table 1). The average yield of extracts were calculated as $9.24 \%, 7.41 \%, 7.252 \%$ and $8.70 \%$ for first, second, third and fourth flushes but the result did not showed any discrete trendline with the number of flushes and there was no statistically different obtained $(p>0.05)$. Therefore, we assumed that the number of flushes has no effect on the yield of mushroom extract.

Table 1 Moisture content of mushroom fruit body and total yield of mushroom extract.

\begin{tabular}{llllll}
\hline \multirow{2}{*}{ Mushroom species } & Moisture content in & \multicolumn{4}{c}{ Total yield of mushroom extract (\%) } \\
& mushroom fruit body (\%)* & 1st flush & 2nd flush & 3rd flush & 4th flush \\
\hline Schizophyllum commune & $69.26 \pm 1.14^{\mathrm{a}}$ & 6.70 & 9.11 & 7.17 & 9.78 \\
Pleurotus djamor var. djamor & $85.49 \pm 2.29^{\mathrm{c}}$ & 7.00 & 7.40 & 5.13 & 10.64 \\
Pleurotus pulmonarius & $81.79 \pm 1.16^{\mathrm{bc}}$ & 10.14 & 6.43 & 7.36 & 5.26 \\
Pleurotus djamor var. roseus & $77.82 \pm 1.47^{\mathrm{b}}$ & 11.32 & 6.41 & 9.34 & 5.81 \\
Pleurotus ostreatus & $78.52 \pm 1.60^{\mathrm{b}}$ & 11.04 & 7.70 & 7.26 & 12.01 \\
\hline
\end{tabular}

*Confident intervals of moisture content were calculated at $95 \%$ confident interval $(\mathrm{p}<0.05)$ in one-way analysis of variance (ANOVA) test.

${ }^{\text {abcd }}$ Different small letters indicated that there was a significant difference among sample.

\section{Scavenging effect on 2,2-diphenyl-1-picrylhydrazyl (DPPH) radicals}

The macrofungi extract showed positive antioxidant activity by fading the violet colour of DPPH solution to yellow and pale violet. The scavenging activities of radical were in direct proportion with the concentrations of the extracts. As the concentration of extract was increased, the scavenging activity towards DPPH radicals was also elevated. The results in this assay were presented as concentration of extracts capable to inhibit $50 \%$ of radical solution $\left(\mathrm{IC}_{50}\right.$ value $)$ where the extract with the lowest $\mathrm{IC}_{50}$ value was the greatest antioxidant holder.

The $\mathrm{IC}_{50}$ values varied from $2.75 \mathrm{mg} / \mathrm{ml}$ to $12 \mathrm{mg} / \mathrm{ml}$ for all samples tested (Table 2). Generally, the inhibition of DPPH radical by $S$. commune extracts showed the highest activity compared to other macrofungi extract for all flushes. The $\mathrm{IC}_{50}$ value for $S$. commune were as low as $2.75 \mathrm{mg} / \mathrm{ml}$ to $3.75 \mathrm{mg} / \mathrm{ml}$ and the extract from $4^{\text {th }}$ flush was assumed to be the strongest inhibitor which showed $50 \%$ inhibition of DPPH free radicals at the lowest concentration $(2.75 \mathrm{mg} / \mathrm{ml})$ among all tested extracts. On average, the strength of mushroom extracts to inhibit $50 \%$ DPPH 
Table 2 Inhibition concentration at 50\% (IC50) values of ethanolic mushroom extracts.

\begin{tabular}{lllll}
\hline Mushroom species & \multicolumn{4}{l}{$\mathbf{I C}_{\mathbf{5 0}}$ of DPPH radical by mushroom extracts (mg/ml)* } \\
\cline { 2 - 5 } & $\mathbf{1}^{\text {st }}$ flush & $\mathbf{2}^{\text {nd }}$ flush & $\mathbf{3}^{\text {rd }}$ flush & $\mathbf{4}^{\text {th }}$ flush \\
\hline Schizophyllum commune & 3.00 & 3.70 & 3.20 & 2.75 \\
Pleurotus djamor var. djamor & 5.50 & 8.50 & 5.00 & 10.00 \\
Pleurotus pulmonarius & 6.00 & 7.50 & 4.20 & 4.75 \\
Pleurotus djamor var. roseus & 7.50 & 6.50 & 5.50 & 6.50 \\
Pleurotus ostreatus & 12.00 & 11.0 & 7.50 & 5.00 \\
\hline
\end{tabular}

*Concentration of mushrooms extracts to inhibit 50\% of 2,2- diphenylpicrylhydrazil (DPPH) solution

radicals can be simplified as $S$. commune $(3.16 \mathrm{mg} / \mathrm{ml})>P$. pulmonarius $(5.61 \mathrm{mg} / \mathrm{ml})>P$. djamor var. roseus $(6.50 \mathrm{mg} / \mathrm{ml})>P$. djamor var. djamor $(7.25 \mathrm{mg} / \mathrm{ml})>P$. ostreatus $(8.88 \mathrm{mg} / \mathrm{ml})$ accordingly.

\section{Effects on reducing power}

All the mushroom species showed appreciable reducing power activities at certain levels of concentration $(2-10 \mathrm{mg} / \mathrm{ml})$. The greatest ability for reducing the ferricyanide complex to ferrous form was observed in $P$. djamor var. djamor extracts at concentration $10 \mathrm{mg} / \mathrm{ml}$ for both first $(1.226 \pm 0.043)$ and second flushes $(1.230 \pm 0.006)$ as shown in Table 3. However, the results of reducing ability by synthetic antioxidants, BHA $(2.510 \pm 0.172)$ and Quercetin $(2.719 \pm 0.024)$ that served as positive controls were significantly two times higher than activity of mushroom extracts. The strength of the reducing power at concentration $10 \mathrm{mg} / \mathrm{ml}$ was demonstrated as $P$. djamor var. djamor $(0.874)>P$. djamor var. roseus $(0.771)>S$. commune $(0.568)>P$. pulmonarius $(0.429)>$ $P$. ostreatus (0.397) accordingly.

\section{Total phenolic content (TPC)}

The amount of total phenolics in different mushroom species varied from 38.45 to $51.94 \mathrm{mg}$ $\mathrm{TAE} / \mathrm{g}$ of dry weight of crude extract where the extracts from third flush showed greater antioxidant activity values compared to other flushes for all mushrooms tested. However, the statistical analysis showed that the number of flushes had no effect on the phenolic concentration in the extracts $(\mathrm{p}>0.05)$. On average of all four flushes, $P$. djamor var. djamor extract was analyzed to have significantly highest total phenolic content among the tested macrofungi followed by $P$. djamor var. roseus, $P$. pulmonarius, $P$. ostreatus and $S$. commune respectively.

\section{Total Flavonoid Content Assay (TFC Assay)}

Total flavonoid contents in the mushrooms extract varied from $1.40 \pm 0.52$ to $29.80 \pm 0.27 \mathrm{mg}$ $\mathrm{QE} / \mathrm{g}$ of dry weight of extracts. The lowest and highest values can be observed in $S$. commune extract at second and fourth flushes. Statistically, the test showed significant difference between total flavonoid content and the additional of flushes for each mushroom species $(p<0.05)$ in oneway analysis of variance (ANOVA) test.

Mushrooms are preferred as nutritional food or supplement by individuals in search of a healthy diet. This study determined that spilt gill mushroom contained $69.26 \%$ moisture in its fresh bodies while the moisture content in oyster mushroom specimens, Pleurotus spp. is as high as 85.49\%. According to Wong and Chye (2009), the elimination of moisture content may increase the concentration of nutrients in the mushroom and may extend the shelf life of mushroom by inhibiting metabolism reaction that lead to quality deterioration such as enzymatic browning and lipid peroxidation. We found that the most preferable method to apply in antioxidant assays is by using freeze dry technique. However, the drying activity may also cause the water-soluble nutrient such as vitamin B and ascorbic acid to be flushed away with the water and sublimed into gaseous state. 
Table 3 Reducing ability of macrofungi extracts at concentration $10 \mathrm{mg} / \mathrm{ml}$ for all flushes.

\begin{tabular}{|c|c|c|c|c|}
\hline \multirow[t]{2}{*}{ Macrofungi species } & \multicolumn{4}{|c|}{$\begin{array}{l}\text { Reducing ability of extracts }(10 \mathrm{mg} / \mathrm{ml}) \text { based on the number of flushes } \\
\text { Readings of absorbance at } 700 \mathrm{~nm}\end{array}$} \\
\hline & 1st flush & 2nd flush & 3rd flush & 4th flush \\
\hline Schizophyllum commune & $0.44 \pm 0.02^{\mathrm{a}}$ & $0.58 \pm 0.01^{\mathrm{b}}$ & $0.43 \pm 0.00^{\mathrm{a}}$ & $0.82 \pm 0.01^{\mathrm{c}}$ \\
\hline Pleurotus pulmonarius & $0.35 \pm 0.01^{\mathrm{a}}$ & $0.42 \pm 0.01^{\mathrm{b}}$ & $0.42 \pm 0.00^{\mathrm{b}}$ & $0.53 \pm 0.01^{\mathrm{c}}$ \\
\hline Pleurotus osteatus & $0.29 \pm 0.00^{\mathrm{a}}$ & $0.34 \pm 0.01^{\mathrm{b}}$ & $0.38 \pm 0.01^{\mathrm{c}}$ & $0.57 \pm 0.00^{\mathrm{d}}$ \\
\hline Pleurotus djamor var. djamor & $1.23 \pm 0.02^{\mathrm{c}}$ & $1.23 \pm 0.00^{\mathrm{c}}$ & $0.47 \pm 0.00^{\mathrm{a}}$ & $0.57 \pm 0.02^{\mathrm{b}}$ \\
\hline Pleurotus djamor var. roseus & $0.96 \pm 0.00^{\mathrm{a}}$ & $0.48 \pm 0.01^{\mathrm{b}}$ & $0.72 \pm 0.00^{\mathrm{c}}$ & $0.93 \pm 0.00^{\mathrm{d}}$ \\
\hline
\end{tabular}

Each value is expressed as mean $\pm \operatorname{SE}(n=4)$.

Means with small letters indicate significantly different within the species at $95 \%$ confident interval $(p<0.05)$.

The reducing power of a compound is known to be associated with the presence of certain antioxidant agents and reductones such as ascorbic acid (Jayaprakasha et al., 2001; Duh et al., 1999). The extracts acted as electron donor to reduce the ferricyanide $\left(\mathrm{Fe}^{3+}\right)$ to ferrocyanide $\left(\mathrm{Fe}^{2+}\right)$ which turned the yellow solution of test compound containing ferric ion to Pearl's Prussian blue or green to intense blue colour solution (depending on the extracts ability) as the reduced form. As reported by Shimada and colleages (1992), we assumed that reducing power in the mushrooms extract might be due to their hydrogen-donating ability that stabilized the corresponding molecules by accepting hydrogen ions from the extracts and terminating the radical chains. Thus, the properties of reducing capacity may serve as a significant indicator of antioxidant potential of a tested compound as stated by Meir et al. (1995).

In this study, the trend lines for total phenolic content differed between one species to another, which indicates that every species has their own unique strategies in phenolic synthesis and metabolic reaction. The previous literatures stated that the exposure of living cells to variety sources of radicals such as sunlight and chemicals may lead the organisms to develop their own protection systems in both enzymatic and non enzymatic reaction (Ferreira et al., 2009; Arbona et al., 2003). Thus the production of phenolic compounds in fungi is believed to provide adequate defensive mechanisms towards radicals and reactive species of certain chemicals. In earlier discoveries, the total phenolic content for both Pleurotus eryngii and Pleurotus ostreatusi were determined to have $0.03 \mathrm{mg} / \mathrm{g}$ and $0.09 \mathrm{mg} / \mathrm{g}$ of dry weight (Kim et al., 2008), Pleurotus djamor and Pleurotus sajor-caju showed $13.22 \mathrm{mg} / \mathrm{g}$ and $14.43 \mathrm{mg} / \mathrm{g}$ of extract in TPC assay respectively (Puttaraju et al., 2006) while the total phenolic content in Pleurotus ostreatus was analyzed to have $0.71 \mathrm{mg} / \mathrm{g}$ of dry weight (Jayakumar, 2008).

Phenolic compounds such as phenolic acids and tannins are known as major components of antioxidant in plants and mushrooms. Previous literatures reported that genus Pleurous contained several types of phenolic compounds such as vanillic acid (Kim et al., 2008; Puttaraju et al., 2006), myricetin, naringin, homogentisic acid, 5-O-caffeoylquinic acid (Kim et al., 2008), chrysin, rutin (Jayakumar et al., 2008) gentisic acid, gallic acid, protocatechuic acid caffeic acid, tannic acid. syringic acid, cinnamic acid and p-coumaric acid (Kim et al., 2008; Puttaraju et al., 2006). In addition, Ferreira (2009) stated that most antioxidant properties that can be found in mushrooms are mainly in the form of phenolic acids and flavonoids, followed by tocopherols, ascorbic acid and carotenoids. The total phenolic content of the current mushroom extract that ranged from 38.45 to $51.94 \mathrm{mg} \mathrm{TAE} / \mathrm{g}$ extract indicated higher content of phenolic than Persian sour summer pomegranade (Reza et al., 2011), cabbage leaves (Brassica oleracea) and water leaf (Talinum triangulare) (Olajire and Azeez, 2011) which showed 21.03 $\pm 1.51 \mathrm{mg}$ GAE/g extract $22.1 \pm 2.95 \mathrm{mg}$ $\mathrm{QE} / \mathrm{g}$ extract and $49.26 \pm 4.76 \mathrm{mg} \mathrm{QE} / \mathrm{g}$ extract respectively. 


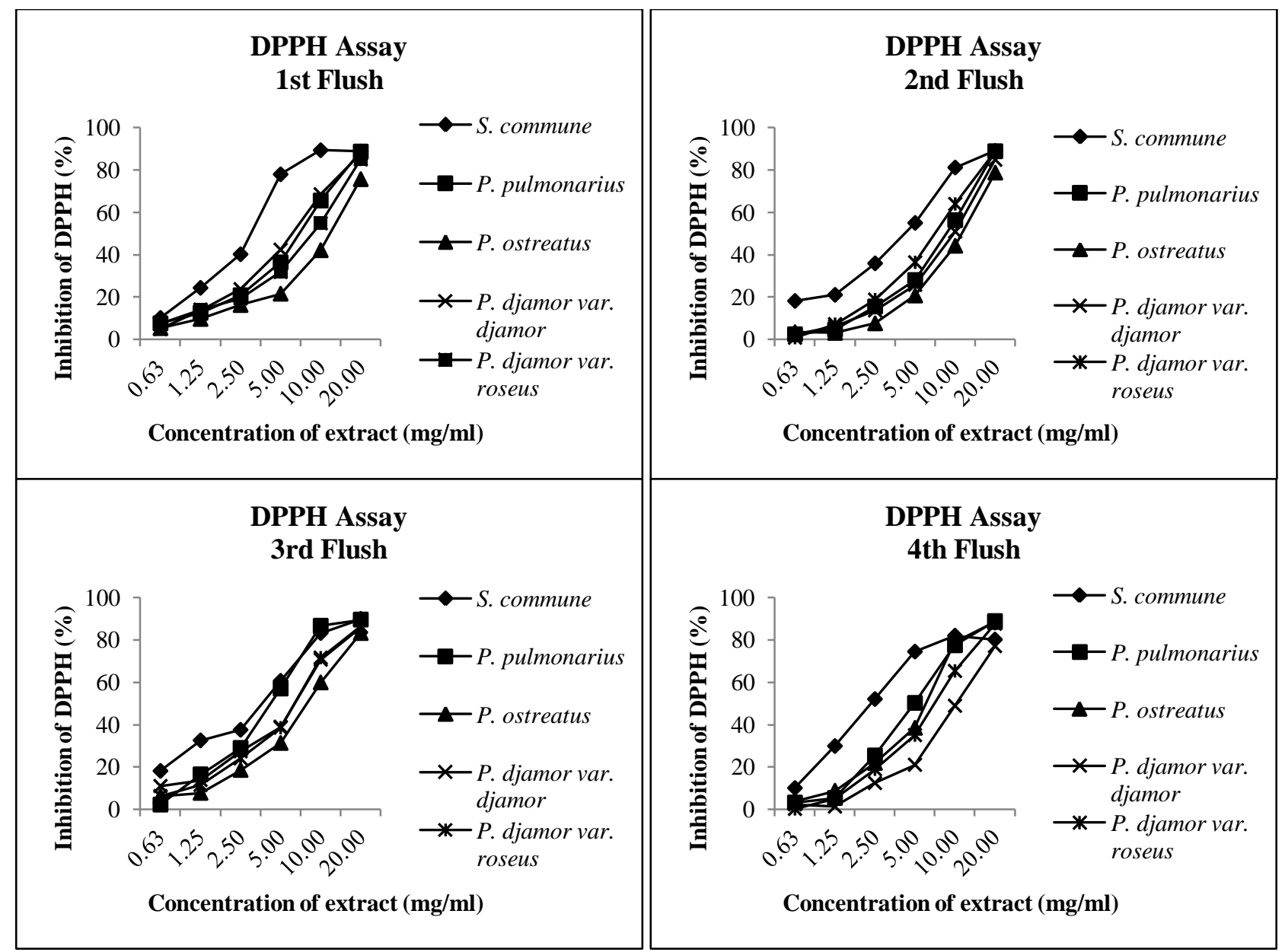

Fig. 6 - Percentage of DPPH radical inhibition by different concentration of macrofungi extract based on number of flushes.

Table 4 Total phenolic and flavonoid content in mushroom extracts.

\begin{tabular}{|c|c|c|c|c|c|c|c|c|c|c|c|c|c|c|c|}
\hline \multirow{2}{*}{$\begin{array}{l}\text { Mushroom } \\
\text { species }\end{array}$} & \multicolumn{7}{|c|}{$\begin{array}{l}\text { Total phenolic content (mg TAE/g dry weight } \\
\text { of extract) }\end{array}$} & \multicolumn{8}{|c|}{$\begin{array}{l}\text { Total flavovoid content (mg QE/g dry weight } \\
\text { of extract) }\end{array}$} \\
\hline & $\mathbf{1}^{\text {st }}$ flush & \multicolumn{2}{|c|}{$2^{\text {nd }}$ flush } & \multicolumn{2}{|c|}{$3^{\text {rd }}$ flush } & \multicolumn{2}{|c|}{$4^{\text {th }}$ flush } & \multicolumn{2}{|c|}{$1^{\text {st }}$ flush } & \multicolumn{2}{|c|}{$2^{\text {nd }}$ flush } & \multicolumn{2}{|c|}{$3^{\text {rd }}$ flush } & \multicolumn{2}{|c|}{$4^{\text {th }}$ flush } \\
\hline$S$ & $\begin{array}{l}40.51 \\
0.72^{b}\end{array}$ & $\begin{array}{l}38.45 \\
0.07^{\mathrm{a}}\end{array}$ & - & $\begin{array}{l}40.99 \\
0.32^{b}\end{array}$ & \pm & & \pm & $\begin{array}{l}1.41 \\
0.49^{\mathrm{a}}\end{array}$ & \pm & & \pm & & \pm & & \pm \\
\hline $\begin{array}{l}\text { P. djamor var. } \\
\text { djamor }\end{array}$ & $\begin{array}{l}51.94 \\
0.67^{d}\end{array}$ & $\begin{array}{l}49.11 \\
1.69^{\mathrm{d}}\end{array}$ & \pm & $\begin{array}{l}50.19 \\
0.98^{d}\end{array}$ & \pm & $\begin{array}{l}39.62 \\
0.27^{\mathrm{e}}\end{array}$ & \pm & $\begin{array}{l}14.88 \\
2.13^{\mathrm{d}}\end{array}$ & \pm & $\begin{array}{l}7.48 \\
1.42^{\mathrm{de}}\end{array}$ & \pm & & \pm & $\begin{array}{l}3.02 \\
0.75^{\mathrm{f}}\end{array}$ & \pm \\
\hline arius & $\begin{array}{l}39.36 \\
0.19^{f}\end{array}$ & $\begin{array}{l}43.05 \\
0.34^{\mathrm{g}}\end{array}$ & \pm & $\begin{array}{l}44.90 \\
0.94^{\mathrm{h}}\end{array}$ & \pm & & \pm & $\begin{array}{l}7.56 \\
1.34^{\mathrm{g}}\end{array}$ & \pm & $\begin{array}{l}8.61 \\
2.76^{\mathrm{g}}\end{array}$ & \pm & & \pm & & \pm \\
\hline $\begin{array}{l}P . \text { djamor var. } \\
\text { roseus }\end{array}$ & $\begin{array}{l}43.89 \\
0.99^{\mathrm{i}}\end{array}$ & $\begin{array}{l}41.81 \\
0.15^{\mathrm{i}}\end{array}$ & \pm & $\begin{array}{l}43.07 \\
0.27^{\mathrm{i}}\end{array}$ & \pm & $\begin{array}{l}46.55 \\
1.06^{j}\end{array}$ & \pm & $\begin{array}{l}5.66 \\
1.92^{h}\end{array}$ & \pm & $\begin{array}{l}6.29 \\
1.92^{\text {hi }}\end{array}$ & \pm & $\begin{array}{l}5.38 \\
0.62^{\mathrm{h}}\end{array}$ & \pm & $\begin{array}{l}8.42 \\
2.22^{\mathrm{i}}\end{array}$ & \pm \\
\hline P. ostreatus & $\begin{array}{l}40.23 \\
0.44^{\mathrm{k}}\end{array}$ & $\begin{array}{l}41.91 \\
0.63^{1}\end{array}$ & \pm & $\begin{array}{l}43.91 \\
0.30^{\mathrm{m}}\end{array}$ & \pm & $\begin{array}{l}42.83 \\
0.461^{\mathrm{m}}\end{array}$ & \pm & $\begin{array}{l}3.39 \\
2.72^{\mathrm{j}}\end{array}$ & \pm & $\begin{array}{l}11.61 \\
3.21^{\mathrm{k}}\end{array}$ & \pm & $\begin{array}{l}12.97 \\
2.43^{\mathrm{k}}\end{array}$ & \pm & $\begin{array}{l}11.57 \\
2.91^{\mathrm{k}}\end{array}$ & \pm \\
\hline
\end{tabular}

${ }^{\mathrm{A}}$ Total phenolic content was calculated using tannic acid equivalent (TAE) which resembled as linear equation, $\mathrm{y}=$ $0.624 \mathrm{x}-0.939$, where $\mathrm{R}^{2}=0.995$.

${ }_{\mathrm{B}}^{\mathrm{B}}$ Total flavonoid content was expressed as quercetin equivalent (QE) which resembles as linear equation, $\mathrm{y}=0.016 \mathrm{x}-$ 0.031 , where $\mathrm{R}^{2}=0.991$.

${ }^{*}$ Each value was expressed as mean $\pm \mathrm{SE}$ ( $\mathrm{n}=3$ for total phenolic content and $\mathrm{n}=6$ for total flavonoid content). The mean differences were significant at the 0.05 level in one-way analysis of variance (ANOVA) test. 


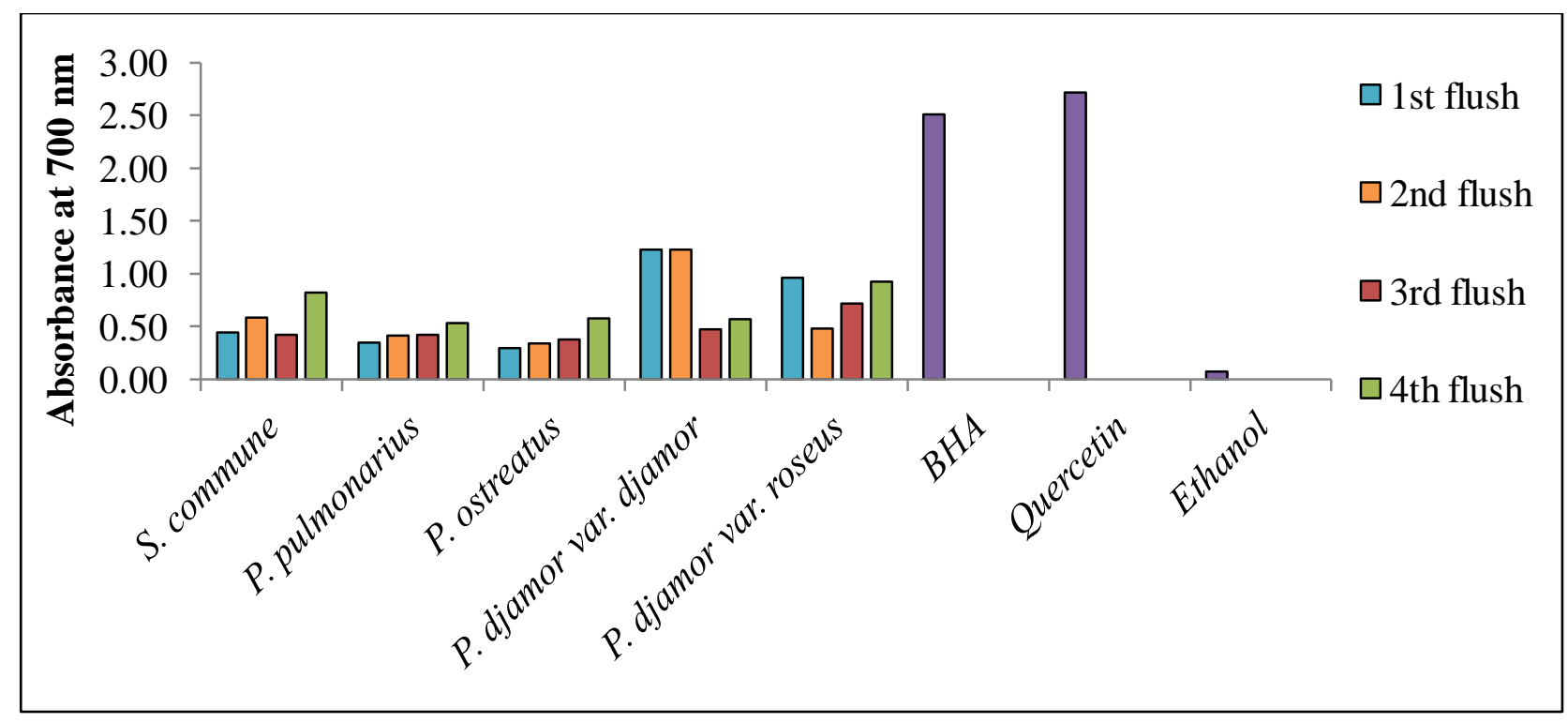

Fig. 7 - Reducing power of macrofungi extracts at concentration $10 \mathrm{mg} / \mathrm{ml}$ towards ferricyanide complex with both BHA and Quercetin as positive controls and ethanol as negative control.

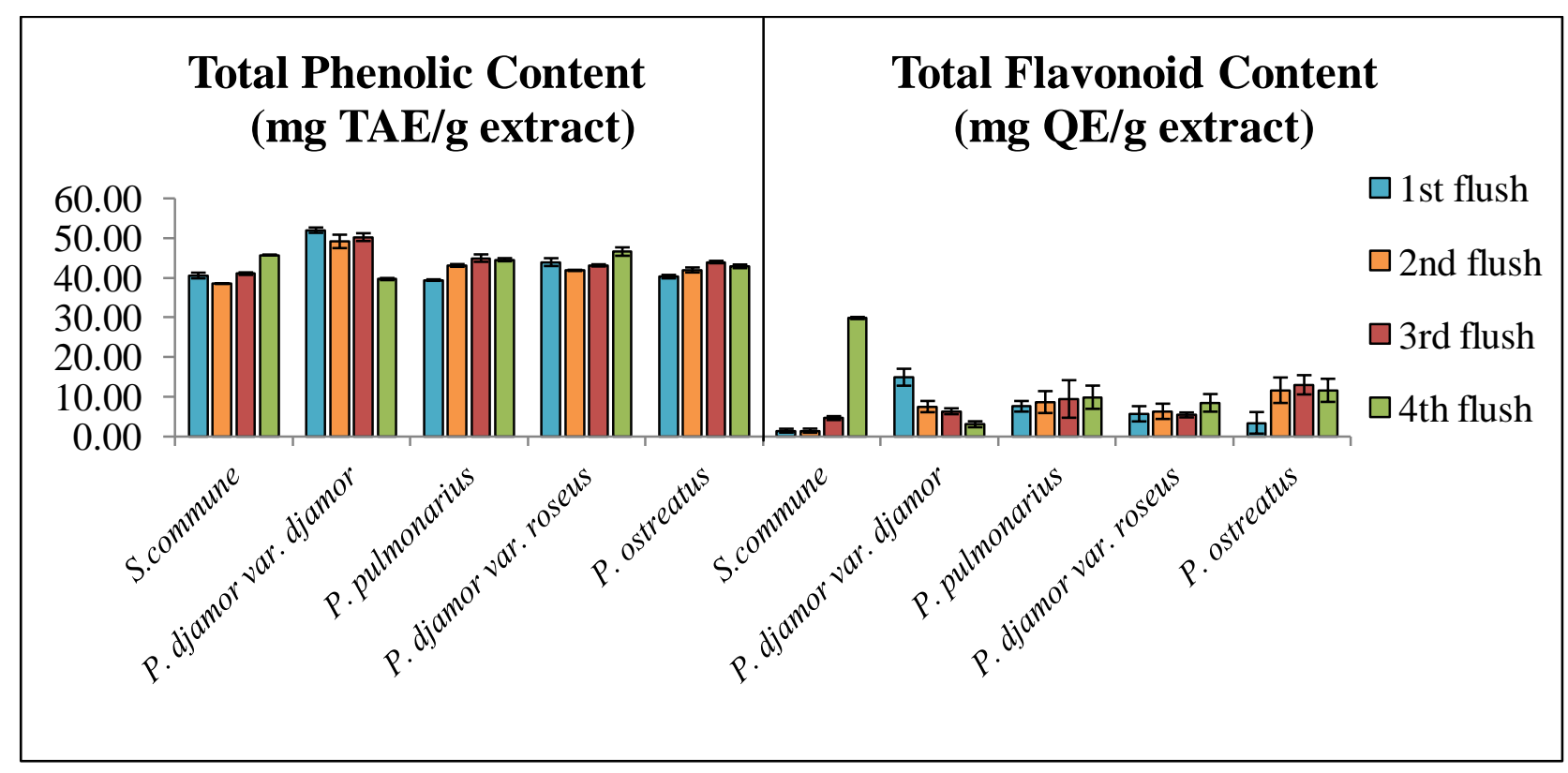

Fig. 8 - Concentration of total phenolic and total flavonoid content in ethanolic extracts of tested macrofungi.

The TFC assay was estimated to extract flavonoids, isoflavonoids and neoflavonoids or collectively called as bioflavonoids. This ketone containing compounds will form acid stable complexes with the C-4 keto group and either the C-3 and C-5 hydroxly group of bioflavonoids. However, this method showed limitation to estimate flavanoid, the none-ketone group flavonoid. According to Mohy et al., (2009), flavanoids responded poorly in aluminium chloride colorimetric method but reacted well with the presence of 2,4-dinitrophenylhydrazine. Reversely, flavonols and isoflavones with C2-C3 double bond could not react with 2,4-dinitrophenylhydrazine but worked best in aluminium chloride.

Several studies have demonstrated that flavonoid may act as antioxidant by breaking the radical chains into more stable products in liver microsomal membranes, with ability to protect low density lipoprotein or LDL from being demolished by heavy metals and macrophages (Van Acker 
et al., 1998) and also play an important role to provide instinctive protection against oxidative stress and side effects by its contribution with vitamins. By comparing with previous literatures, all mushroom samples showed higher total flavonoid content than Persian sour summer pomegranade, $1.46 \mathrm{~g} \mathrm{CE} / \mathrm{g}$ extract (Reza et al., 2011). The total flavonoid content of split gill mushroom extract from fourth flush (29.80 mg QE/g extract) is determined to have higher value than African eggplant leaf and stem (Solanum macrocarpon), onion bulb (Allium cepa), bird's eye chilli (Capsicum frutescens), Malabar spinach (Basella alba) and cabbage leaves (Brassica oleracea) which showed $10.23 \mathrm{mg}$ QE/g extract, $12.62 \mathrm{mg}$ QE/g extract, $24.78 \mathrm{mg}$ QE/g extract, 26.53 and $19.29 \mathrm{mg}$ QE/g extract respectively (Olajire and Azeez, 2011).

With the established antioxidant activities of the mushrooms extracts, we suggest that the chemical characteristics of the oxidative components and phytochemicals in the extracts should be further investigated for the development of medicinal mushrooms in the pharmaceutical industry. On the other hand, the discoveries and experimentation of nutritional content and antioxidant properties in wild edible mushrooms are most encouraged because of their unknown medicinal potential.

\section{Acknowledgements}

The authors gratefully appreciate the financial assistance provided by the Graduate Research Fellowship (GRF) and Malaysian Fundamental Research Grant Scheme (FRGS) from Universiti Putra Malaysia and Ministry of Higher Education, Malaysia. We also wish to thank the Department of Biology, Faculty of Science, Universiti Putra Malaysia (UPM) and University Agriculture Park, UPM for the use of their instrumentation facilities.

\section{References}

Aksu S, Işık SE, Erkal S. 1996 - Development of cultivated mushroom production in Turkey and general characteristics of mushroom establishment. Fifth National Congress of Edible Mushrooms (pp. 1-13). Turkey.

Arbona V, Flors V, Jacas J, García-Agustín P, Gómez-Cadenas A. 2003 - Enzymatic and nonenzymatic antioxidant responses of Carrizo citrange, a salt-sensitive citrus rootstock, to different levels of salinity. Plant and Cell Physiology 44(4), 388-94. Retrieved from http://www.ncbi.nlm.nih.gov/pubmed/12721379.

Barros L, Falcão S, Baptista P, Freire C, Vilas-Boas M, Ferreira ICFR. 2008 - Antioxidant activity of Agaricus sp. mushrooms by chemical, biochemical and electrochemical assays. Food Chemistry 111(1), 61-66. doi:10.1016/j.foodchem.2008.03.033.

Bejma J, Ji LL. 1999 - Aging and acute exercise enhance free radical generation in rat skeletal muscle. Journal of Applied Physiology (Bethesda, Md. : 1985) 87(1), 465-70. Retrieved from http://www.ncbi.nlm.nih.gov/pubmed/10409609.

Bloise MS. 1958 - Antioxidant determination by the use of stable free radicals. Nature 181, 11992000.

Chang H, Ho Y, Sheu M, Lin Y, Tseng M, Wu S, Huang G. 2007 - Antioxidant and free radical scavenging activities of Phellinus merrillii extracts. Botanical Studies 48, 407-417.

Chang ST. 2001 - Mushrooms and mushroom cultivation. Chichester: John Wiley \& Sons Ltd.

Duh PD, Tu YY, Yen GC. 1999 - Antioxidant activity of aqueous extract of Hamjyur (Chrsanthemum morifolium Ramat). Lebensmwiss Technology 32, 269-277.

Duru ME, Mercan N. 2007 - Antioxidant and antimicrobial activity of Russula delica Fr : An edible wild mushroom. Eurasian Journal of Analytical Chemistry 2(1), 54-67.

Ferreira ICFR, Barros L, Abreu RMV. 2009 - Antioxidants in wild mushrooms. Current Medicinal Chemistry 16(12), 1543-60. Retrieved from http://www.ncbi.nlm.nih.gov/pubmed/19355906

Halliwell B. 1996 - Antioxidants in human health and disease. Annual Review of Nutrition 16, $33-$ 50. doi:10.1146/annurev.nu.16.070196.000341. 
Harborne. 1989 - General procedures and measurement of total phenolics. Methods in plant biochemistry (Volume 1, pp. 1-28). London: Academic Press.

Ishak MHA. 2011 - Bil 3/2011 Edisi MAC. Berita Tansformasi Pertanian, Bil. 3 (Inovasi Projek Pengeluaran Cendawan PPK Paya Perlis).

Jagadish LK, Venkata V, Shenbhagaraman R, Kaviyarasan V. 2009 - Comparitive study on the antioxidant, anticancer and antimicrobial property of Agaricus bisporus (J. E. Lange) Imbach before and after boiling. African Journal of Biotechnology 8(4), 654-661.

Jayakumar T, Thomas PA, Geraldine P. 2009 - In-vitro antioxidant activities of an ethanolic extract of the oyster mushroom, Pleurotus ostreatus. Innovative Food Science \& Emerging Technologies 10(2), 228-234. doi:10.1016/j.ifset.2008.07.002.

Jayaprakasha GK, Singh RP, Sakariah KK. 2001 - Antioxidant activity of grape seed (Vitis vinifera) extracts on peroxidation models in vitro. Food Chemistry 73(3), 285-290. doi:10.1016/S0308-8146(00)00298-3.

Kalberer R, Kunsch U. 1974 - Amino acid composition of the oyster mushroom (Pleurotus ostreatus). Lebensmittel-Wissenschaft \& Technologie 7, 242-244.

Kim MK, Math RK, Cho KM, Shin K J, Kim JO, Ryu JS, Lee YH, et al. 2008 - Effect of Pseudomonas sp. P7014 on the growth of edible mushroom Pleurotus eryngii in bottle culture for commercial production. Bioresource Technology 99(8), 3306-8.

Kumari D, Achal V. 2008 - Effect of different substrates on the production and non-enzymatic antioxidant activity of Pleurotus ostreatus (Oyster mushroom). Life Science Journal 5(3) 73 76.

Martos ET. 2011 - Cultivation of Pleurotus sajor-caju on banana stalk and Bahia grass based substrates. Horticultura Brasileira 29, 199-204.

Meir S, Kanner J, Akiri B, Philosoph-Hadas S. 1995 - Determination and involvement of aqueous reducing compounds in oxidative defense systems of various senescing leaves. Journal of Agricultural and Food Chemistry 43(7), 1813-1819. doi:10.1021/jf00055a012.

Mohy-ud-din A, Khan Z, Ahmad M, Kashmiri MA, Yasmin S, Mazhar H, Product P, et al. 2009 Chemotaxonomic significance of flavonoids in the solanum nigrum complex. Journal of the Chilean Chemical Society 54(4), 486-490

Moure Â, Cruz JM, Franco D, Domõânguez JM, Sineiro J, Domõânguez H, Jose M, et al. 2000 Natural antioxidants from residual sources. Food Chemistry 72, $145-171$.

Norouzi A, Peyvast G, Olfati J. 2008 - Oilseed rape straw for cultivation of oyster mushroom. Journal of Science and Technology 2(03), 502-507.

Okhuoya JA, Okogbo FO. 1991 - Cultivation of Pleurotus tuber-regium ( Fr ) Sing on Various Farm Wastes. Proceedings of the Oklahoma Academy of Science 3, 1-3.

Olajire AA, Azeez L. 2011 - Total antioxidant activity, phenolic, flavonoid and ascorbic acid contents of Nigerian vegetables. African Journal of Food Science and Technology 2(2), 2229.

Oyaizu M. 1986 - Studies on products of the browning reaction. Antioxidative activities of browning reaction products prepared from glucosamine. Japanese Journal of Nutrition 44.6, 307-315.

Poon HF, Calabrese V, Scapagnini G, Butterfield DA. 2004 - Free radicals: key to brain aging and heme oxygenase as a cellular response to oxidative stress. The journals of gerontology. Series A, Biological sciences and medical sciences 59(5), 478-93. Retrieved from http://www.ncbi.nlm.nih.gov/pubmed/15123759.

Puttaraju NG, Venkateshaiah SU, Dharmesh SM, Urs SMN, Somasundaram R. 2006 - Antioxidant activity of indigenous edible mushrooms. Journal of agricultural and food chemistry 54(26), 9764-72. doi:10.1021/jf0615707.

Reza M, Ardekani S, Hajimahmoodi M. 2011 - Comparative antioxidant activity and total flavonoid content of persian pomegranate (Punica granatum L.) Cultivars. Iranian Journal of Pharmaceutical Research 10, 519-524. 
Shimada K, Fujikawa K, Yahara K, Nakamura T. 1992 - Antioxidative properties of xanthan on the autoxidation of soybean oil in cyclodextrin emulsion. Journal of Agricultural and Food Chemistry 40(6), 945-948.

Wei Y, Lee H. 2013 - Oxidative Stress, Mitochondrial DNA Mutation, and Impairment of Antioxidant Enzymes in Aging. Experimental Biology and Medicine 227, 671-682.

Tsai SY, Huang SJ, Lo SH, Wu TP, Lian PY, Mau JL. 2009 - Flavour components and antioxidant properties of several cultivated mushrooms. Food Chemistry 113(2), 578-584. doi:10.1016/j.foodchem.2008.08.034.

Van Acker SA, Van Balen GP, Van den Berg DJ, Bast A, Van der Vijgh WJ. 1998 - Influence of iron chelation on the antioxidant activity of flavonoids. Biochemical Pharmacology 56(8), 935-43. Retrieved from http://www.ncbi.nlm.nih.gov/pubmed/9776303

Wong JY, Chye FY. 2009 - Antioxidant properties of selected tropical wild edible mushrooms. Journal of Food Composition and Analysis 22(4), 269-277. doi:10.1016/j.jfca.2008.11.021 